\title{
KTT STRATEGIES FOR SCIENTIFIC INSTITUTIONS: UNDERSTANDING THE PAST TO HELP BUILD THE FUTURE
}

\author{
ESTRATÉGIAS DE TRANSFERÊNCIA DE CONHECIMENTO \\ E TECNOLOGIA DAS INSTITUIÇÕES CIENTÍFICAS: \\ COMPREENDER O PASSADO PARA AJUDAR A CONSTRUIR \\ O FUTURO.
}

Submission: $16 / 04 / 2021$

Accept: 11/10/2021

Matheus Dantas Madeira Pontes ${ }^{1}$

Thayanne Lima Duarte Pontes ${ }^{2}$

1 University of International Integration of Afro-Brazilian Lusophony (PROPLAN/UNILAB). Redenção, Ceará, Brazil.

2 University of Beira Interior (NECE/UBI). Covilhã, Portugal.

\begin{abstract}
Purpose - This paper aims to identify the current situation of the research that analyzes KTT strategies in scientific institutions.

Design/methodology/approach - To systematize the empirical evidence that emerged from academic debates in the field, the study breaks down, through a Systematic Literature Review (SLR), 42 papers from the Web of Science database. The author divides the sample into three clusters: environmental impact, institutional effectiveness, and individual strategies, according to its unit of analysis.

Findings - The findings indicate that the alignment of KTT activities with the strategic objectives of the institutions is fundamental for positive outcomes. In addition to that, the resources for obtaining relevant results are the quality and the availability of human capital in scientific institutions, public companies, and support organizations. Finally, there is a stream of research that criticizes the exclusively commercial approach of the phenomenon.

Research limitations - The Web of Science database relies on being the manly coverage for scientific publications in general. So, due to the choice for composing this sample with papers written only in English, untranslated studies were excluded from this analysis.

Originality/value - The contribution for Literature relies on proposing a future research agenda based on identified gaps and current topics, discussing the results of previous studies that can support the decision-making of these organizations at developing efficient KTT strategies for themselves.
\end{abstract}

Keywords: Knowledge and Technology Transfer; Strategies; Systematic Literature Review; Knowledge Dissemination; Scientific Institutions. 


\section{RESUMO}

Objetivo - O objetivo da investigação é identificar o estado da arte da pesquisa dedicada à análise das estratégias de Transferência de Conhecimento e Tecnologia (TCT) em instituições científicas.

Desenho/metodologia/abordagem - Através de uma Revisão Sistemática de Literatura (RSL), 42 artigos da base de dados Web of Science foram analisados para sistematizar as principais evidências empíricas que surgiram do debate acadêmico. A amostra foi dividida em três grupos - Impacto Ambiental, Eficácia Institucional e Estratégias Individuais - de acordo com a unidade de análise dos pesquisadores.

Resultados - Os resultados indicam que o alinhamento das atividades de TCT com os objetivos estratégicos das instituições é fundamental para resultados positivos. O principal recurso para a obtenção de resultados relevantes é a qualidade e disponibilidade de capital humano em instituições científicas, setor público, empresas ou organizações de apoio. Existe, ainda, uma corrente de pesquisas que critica a abordagem exclusivamente comercial do fenômeno.

Limitações da Pesquisa - Apesar da Web of Science ser a plataforma com maior cobertura científica, outras bases de dados não foram consultadas. Devido a opção de compor a amostra com artigos escritos na língua inglesa, trabalhos não traduzidos foram excluídos da análise.

Originalidade/valor - 0 trabalho apresenta contribuições para a literatura propondo uma agenda de pesquisa futura a partir das lacunas identificadas e temas atuais; e, para instituições científicas, discutindo resultados de estudos anteriores que podem subsidiar essas organizações no desenvolvimento de suas próprias estratégias de TCT.

Palavras-chave: Transferência de conhecimento e tecnologia; Estratégias; Revisão Sistemática da Literatura; Disseminação de Conhecimento; Instituições científicas.

\section{INTRODUCTION}

Education and scientific research are examples of activities that promote positive externalities to society (Autant-Bernard, 2001). This phenomenon occurs when a new service generates benefits beyond direct consumers without extra financial compensations, commonly justifying government involvement in science and education to foment innovation, capabilities, and the creation of new technologies (Hall, 2006).

In this context, universities should solidify their role as promoters of societies by encouraging a debate about the changes in the understanding of knowledge diffusion and its impacts on the economic environment (Laredo, 2007). This process resulted in the development of the higher education sector's third mission, in which universities must connect themselves with external actors to transfer knowledge and technologies, seeking mutual benefits (Wu \& Zhou, 2012). The importance of the third mission to universities is evident since it is possible to verify references to its different approaches in strategic mission and vision in several institutions (Giusepponi \& Tavoletti, 2018). Identifying successful Knowledge and Technology Transfer (KTT) strategies, thus, can contribute to the achievement of institutional objectives in the research sector and generate competitiveness to different stakeholders.

The author defines KTT as activities aimed at transferring knowledge or technology that could help both companies and academic institutions involved in a collaborative partnership to help to pursue its goals (Arvanitis et al., 2008). Battistela et al. (2016), in a critical literature review, remembered that inter-organizational technology/knowledge transfer is an emergent topic and has been the subject of countless studies. The positive impacts of KTT on the economy explains its popularity since previous research found evidence that knowledge and technology transfer can result in additional revenue for scientific institutions, employment opportunities for graduate students, technological spillovers through the stimulation of R\&D investment, and job creation (Siegel et al., 2007).

Literature, however, has yet to develop a specific theoretical framework for KTT strategies (Arvanitis \& Woerter, 2009). The economic, social, and political contexts shape the knowledge and 
technology transfer practices (Bercovitz \& Feldman, 2006). Those are the reasons for the relevance of studying these processes under the paradigms of strategic management. Audretsch (2014) adverted that, due to the rapid growth of multinational companies, the current focus of technology transfer relies on the research of comparative advantages within the global competition. New players, facilitated by more open economies and technical advances in transport and communication, challenge existing comparative advantages and competitiveness of countries and regions.

A variety of research explores how strategic management contributes to organizations shaping the market structures in their favor (Eloranta \& Turunen, 2015). Competitive advantages depend on the ability of companies to adapt skills and resources in a dynamic environment (Teece, 2007). Companies achieve those advantages through strategic alliances in the business ecosystem (Lavie, 2006). Strategic actions, thus, can be used to manipulate the market environment and strengthen companies' performance (Helfat \& Peteraf, 2003). The scientific institutions realized the importance of strategic management, using its techniques to develop a vision for the future to come. They also should learn how to deal with environmental challenges (Diniz \& de Castro, 2010). Connecting KTT initiatives to strategic management might enhance technological accessibility for the industry since this discipline helps organizations by showing them how core competencies can be introduced, nurtured, and sustained (Major, 2003).

A little-explored path refers to the understanding of how different types of innovative activities should be managed (Keupp et al., 2012). Despite the recognition that scientific institutions must develop strategies to promote technology transfer naturally (Sousa et al., 2019), most literature reviews in this field focus on the analysis of KTT from the perspective of cooperation (Mascarenhas et al., 2018), internationalization (Govind \& Küttim, 2017), and innovation (Hadengue et al., 2017). The current debate relies on the duty of scientific institutions to expand their environment from conservator to originator of knowledge (Etzkowitz, 2013). Such discussions have not yet consolidated a theoretical framework on KTT strategies and their implications. Overcoming the gap of analysis of the KTT from a strategic management perspective is essential for the maturing of the field, considering that this knowledge is a resource for creating competitive advantages for organizations. (Bou-Llusar \& Segarra-Ciprés, 2006).

Klofsten et al (2019) understood the importance of universities for social change and economic growth. He proposed a research method that focuses on strategies for knowledge transfer and the exploration of relationships between universities ecosystems and the business sector since modern organizations must investigate their research activities and create a strategic transfer plan to directly respond to the needs of society (Szopa, 2015). Deiaco et al (2012), however, argued that the dynamics of scientific institutions are changing. He also says that the growing competition for resources, conditioned by national and international systems, increases the need for understanding the transfer of knowledge from a strategic perspective. Thus, this investigation seeks to answer the following question: what is the current situation for research on KTT strategies of scientific institutions?

Admitting that the knowledge and the technology transfer processes between universities and companies are complex and involve multiple factors (Perkmann et al., 2013), this research focused on KTT strategies implemented by different players and their implications. To investigate the partnership through a strategic management view could enhance KTT literature. This partnership allows an understanding of the phenomena from multiple perspectives, and it might show the entities as dynamic and malleable actors (Nag et al., 2007). An unplanned growth in literature can impede advancement by introducing competition and some counter-intuitive arguments in the scholarly dialogue (Kraus et al., 2021). In this context, the study contributes to a clear understanding of the advancements and the state of knowledge stock in the field, enabling scientific institutions to select and adopt empirically validated KTT strategies. 
Through a Systematic Literature Review (SLR), the paper aims to identify prominent publications about scientific institutions and their KTT strategies and to discuss their key findings. Assuming that SLR is a useful method to save researchers' time and effort in identifying paramount agenda (Webster \& Watson, 2002), it is expected that this study could contribute to literature advance by suggesting investigations paths that could become avant-garde soon in the future. The SLR technique allows understanding the past since the synthesis of previous works helps to consolidate the existing literature in a certain field. At the same time, it aims to shape the future, offering the possibility of combining existing investigations with the creation of solid definitions and foundations for further research (Kraus et al., 2020).

In addition to this introduction, the paper contains other five sections. In the methodology section, the procedures adopted for the sample selection and treatment are discussed. Afterward, the descriptive analysis part presents important characteristics (evolution of the research, prominent authors, main sources of publication, typology of studies, and location of research) of KTT strategies investigation. The fourth section describes and details the identified clusters. In the discussion section, the results are contrasted with previous literature, illustrating their main contributions to the subject. It also serves as an input for the proposition of an agenda for future investigations. Finally, the last section shows the conclusions, limitations, and contributions of the paper.

\section{METHODOLOGY}

To guarantee the study's replicability a systematic review process was followed. This technique generally conveys a greater sense of reliability about investigations in a research field (Petticrew \& Roberts, 2006). Its purpose involves identifying, examining, and synthesizing all relevant studies carried out in a replicable and transparent process (Tranfield et al., 2003). An SLR protocol was undertaken based on the guidelines proposed by Siddaway et al. (2019).

The protocol consists of:

1. Search strategy.

2. Study selection criteria.

3. Research selection procedures.

4. Data extraction strategy; and

5. Quality evaluation of the study.

Table 1 presents the elements considered for each stage of the protocol. The selection of the sample was delimitated by articles published in English, on any date, from peer-reviewed journals in the fields of Management, Business, and Economics at the Web of Science (WOS) database (Malerba \& Ferreira, 2020). WOS platform is the oldest and has the most coverage of journals and papers among the most used scientific databases (Vieira \& Gomes, 2009). 
Systematic literature review protocol

\begin{tabular}{|c|c|c|}
\hline Stage & Principle & Description \\
\hline \multirow[t]{5}{*}{ Search Strategy } & $\begin{array}{c}\text { Studies typifica- } \\
\text { tion }\end{array}$ & Articles published in peer-reviewed journals. \\
\hline & Keywords & $\begin{array}{c}\text { Strategies; Education Institutions; Science Institutions; Uni- } \\
\text { versities. }\end{array}$ \\
\hline & Search equation & $\begin{array}{c}\text { ("strateg*") AND ("education institution*" OR "science insti- } \\
\text { tution*" OR "universit*") }\end{array}$ \\
\hline & Period & Until September 2020 \\
\hline & Database & Web of Science \\
\hline \multirow[t]{6}{*}{ Study selection criteria } & Criteria & 1) Class notes and book chapters were excluded \\
\hline & & 2) Conference articles were disregarded \\
\hline & & 3) Papers must be in English \\
\hline & Procedures & 1) Titles are selected \\
\hline & & 2) Abstract, introduction and conclusions sections were read \\
\hline & & 3) Full paper has been revised \\
\hline
\end{tabular}

Notes. Elaborated by authors.

KTT is complex and involves numerous activities (Tatikonda \& Stock, 2003), as well as there are several synonyms for this expression (Cottrill et al., 1989). The research focuses on strategies applied by individuals, scientific institutions, and public entities for the spread of knowledge. The term "strategy" was inserted in the database search field, and, afterward, papers that dealt with the intended topic were selected. By limiting the sample to studies with the terms in the title, only articles with a greater emphasis on the area emerged (Mascarenhas et al., 2018).

Universities are the locus of excellence concerning knowledge and technology transfer activities (Curi et al., 2012). For broadening the understanding of such phenomena, it is necessary to consider public and private institutions that emerged in the 19th century that are dedicated to helping startups to capture technology-based market opportunities, such as incubators and accelerators (Hausberg \& Korreck, 2020). The investigation, then, used the Boolean connector "education institution*" OR "science institution*" OR "university*" to capture as much research as possible in this field.

Through search equations and filters, 134 studies were identified in the WOS database. After examining titles, abstracts, and keywords, 84 papers were rejected for non-compliance with the research objectives. Fifty investigations remained for an in-depth reading, including introductions and conclusions. In the end, 42 papers were aligned with the proposed goals, as shown in Figure 1. 


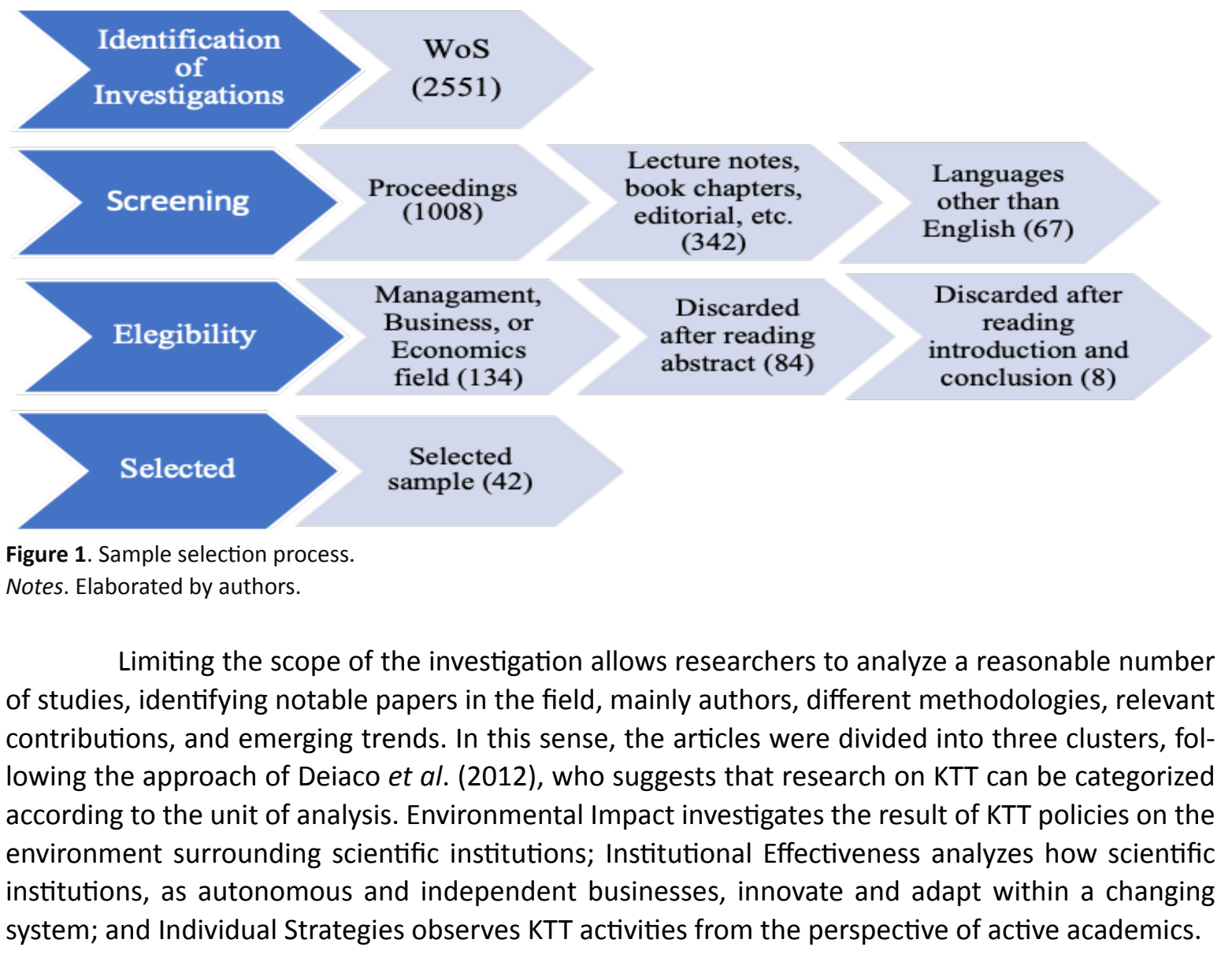

\section{DESCRIPTIVE ANALYSIS}

\subsection{Evolution of the research}

The first contributions to literature are from the year 1998. When considering the decades of publications, it is possible to note, from Figure 2, a concentration of papers between 2011 and 2020. This decade gathers approximately $74 \%$ of all publications, showing that it is a contemporary topic. In the case of citations, the most relevant articles were published between 2000 and 2003, when only 04 papers were responsible for more than $43 \%$ of total citations.

Figure 3 shows a research trend reversal in the last five years. Scientific production migrated from analyzing the impacts of KTT strategies on the external environment to study factors that could enhance (or mitigate) the effectiveness of KTT strategies within research institutions. Although marginally, there is also an increase in papers focused on individuals' strategies for knowledge and technology dissemination. 


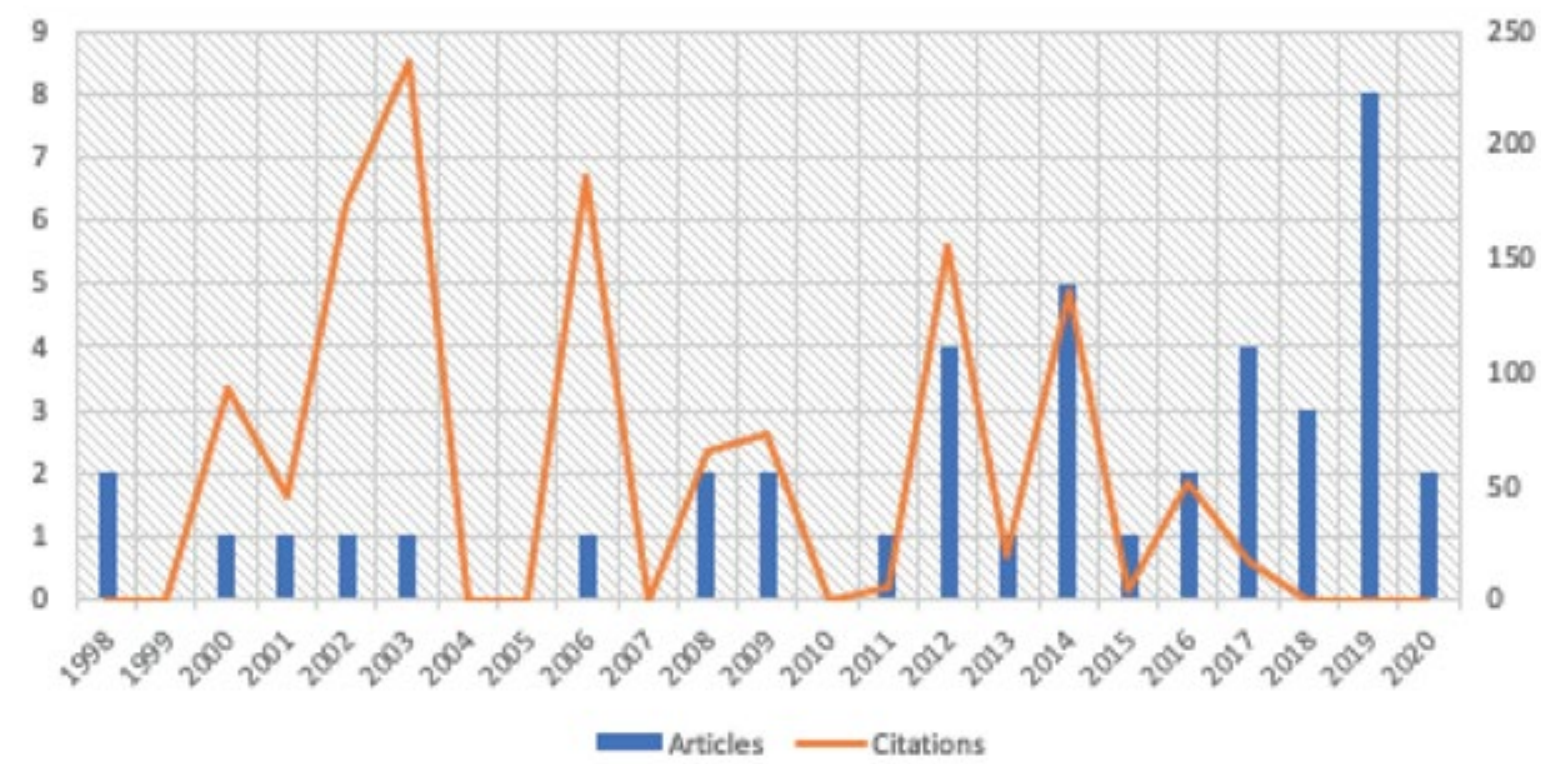

Figure 2. Articles and citations by year. Notes. Elaborated by authors.

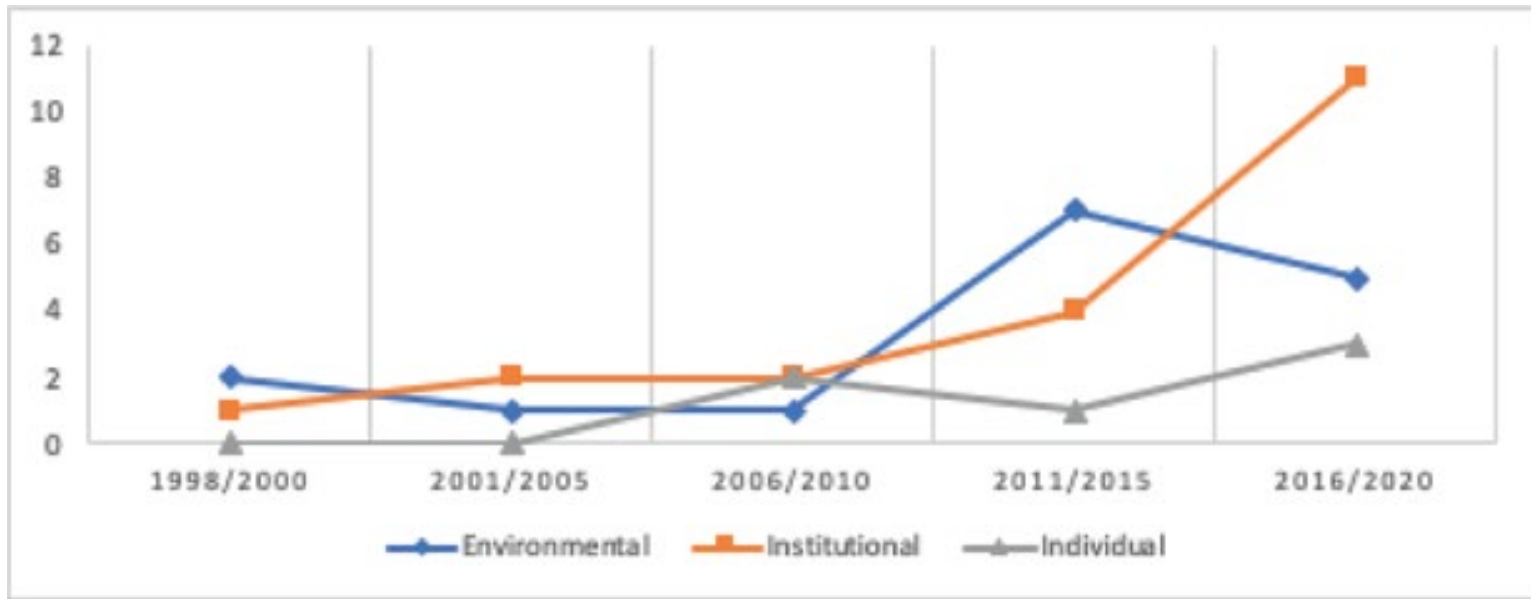

Figure 3. Articles evolution by cluster per 5-year period.

Notes. Elaborated by authors.

\subsection{Prominent authors}

There is a diversity of authors who contributed to literature. In all, 106 researchers were involved in the 42 investigations on KTT strategies in scientific institutions, what represents an average of 2,5 authors per article. Mike Wright (3), Alan Hughes (2), David Urbano (2), Elias G. Carayannis (2), Maribel Guerrero (2), and Shiri M. Breznitz (2) are the scientists with most published work in the field. Table 2 presents top-3 most cited authors (with ties) according to each approach. 
Top-3 most cited authors by cluster

\begin{tabular}{|c|c|c|}
\hline Cluster & Author & Citations \\
\hline \multirow{3}{*}{ Environmental } & Alan Hughes & 131 \\
\hline & Carayannis, Alexander and Ioannidis & 92 \\
\hline & Michael Kitson & 80 \\
\hline \multirow{3}{*}{ Institutional } & Mike Wright & 258 \\
\hline & Lockett and Franklin & 237 \\
\hline & Feldman, Feller, Bercovitz and Burton & 174 \\
\hline \multirow{3}{*}{ Individual } & Ajay Agrawal & 186 \\
\hline & Patzelt and Shepherd & 54 \\
\hline & Guerrero, Herrera and Urbano & 9 \\
\hline
\end{tabular}

Notes. Elaborated by authors.

\subsection{Principal sources}

Twenty-eight journals published the articles in the sample and Table 3 shows the periodicals with at least 10 citations. Technological Forecasting and Social Change was the main disseminator of scientific research in this field. Despite having published only one article, Small Business Economics has the greatest academic impact, largely because of Lockett et al. (2003) seminal paper. Using citations per article to measure academic impact, Table 3 demonstrates that a greater number of articles will not translate into breadth in the knowledge dissemination. Analysis of publication sources by cluster did not identify any pattern.

Table 3

Principal sources of publications and citations.

\begin{tabular}{cccc}
\hline Journal & Article & Citations & Cit/Art \\
\hline Technological Forecasting and Social Change & 6 & 102 & 17,0 \\
Technology Analysis \& Strategic Management & 3 & 31 & 10,3 \\
Science and Public Policy & 3 & 15 & 5,0 \\
Management Decision & 3 & 14 & 4,7 \\
Technovation & 2 & 139 & 69,5 \\
Cambridge Journal of Economics & 2 & 131 & 65,5 \\
Small Business Economics & 2 & 13 & 6,5 \\
Strategic Management Journal & 1 & 237 & 237,0 \\
Management Science & 1 & 186 & 186,0 \\
Journal of Engineering and Technology Management & 1 & 174 & 174,0 \\
Entrepreneurship Theory and Practice & 1 & 56 & 56,0 \\
IEEE Transactions on Engineering Management & 1 & 54 & 54,0 \\
Management Learning & 1 & 46 & 46,0 \\
Cambridge Journal of Regions Economy and Society & 1 & 30 & 30,0 \\
Industrial and Corporate Change & 1 & 25 & 25,0 \\
R\&D Management & 1 & 19 & 19,0
\end{tabular}




\subsection{Typology of the studies}

The sample contains $4(9,5 \%)$ theoretical papers and 38 empirical studies, including 17 $(40,5 \%)$ qualitative, $16(38,1 \%)$ quantitative, and $5(9,5 \%)$ mixed methods investigations. Figure 4 depicts the evolution of different typology approaches over the years. Both qualitative and quantitative methods appear to have the same importance in KTT strategies investigations, with a more significant growth of quantitative research recently. Theoretical work has also been gaining relevance in the last years, in contrast to mixed approaches.

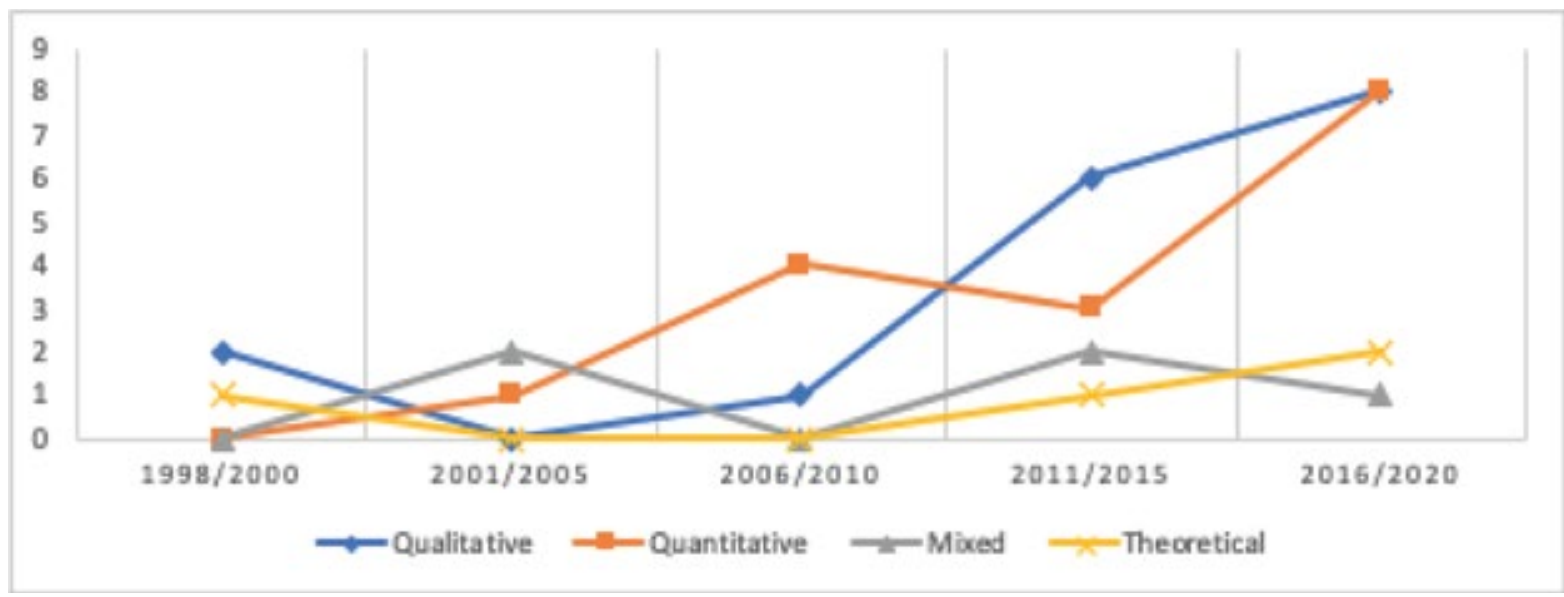

Figure 4. Investigations type by period. Notes. Elaborated by authors.

Typology seems to vary according to the focus of study, as shown in Figure 5. Environmental research mainly used a qualitative approach $(56,3 \%)$, followed by theoretical $(18,7 \%)$, quantitative $(12,5 \%)$, and mixed methods (12,5\%). Papers belonging to Institutional cluster were developed in a quantitative $(50,0 \%)$ perspective mostly. Qualitative $(30,0 \%)$, mixed methods $(15,0 \%)$ and theoretical $(5,0 \%)$ comes next. Research elaborated within Individual cluster opted only for quantitative $(66,6 \%)$ and qualitative $(33,4 \%)$ approach when looking for empirical evidence.

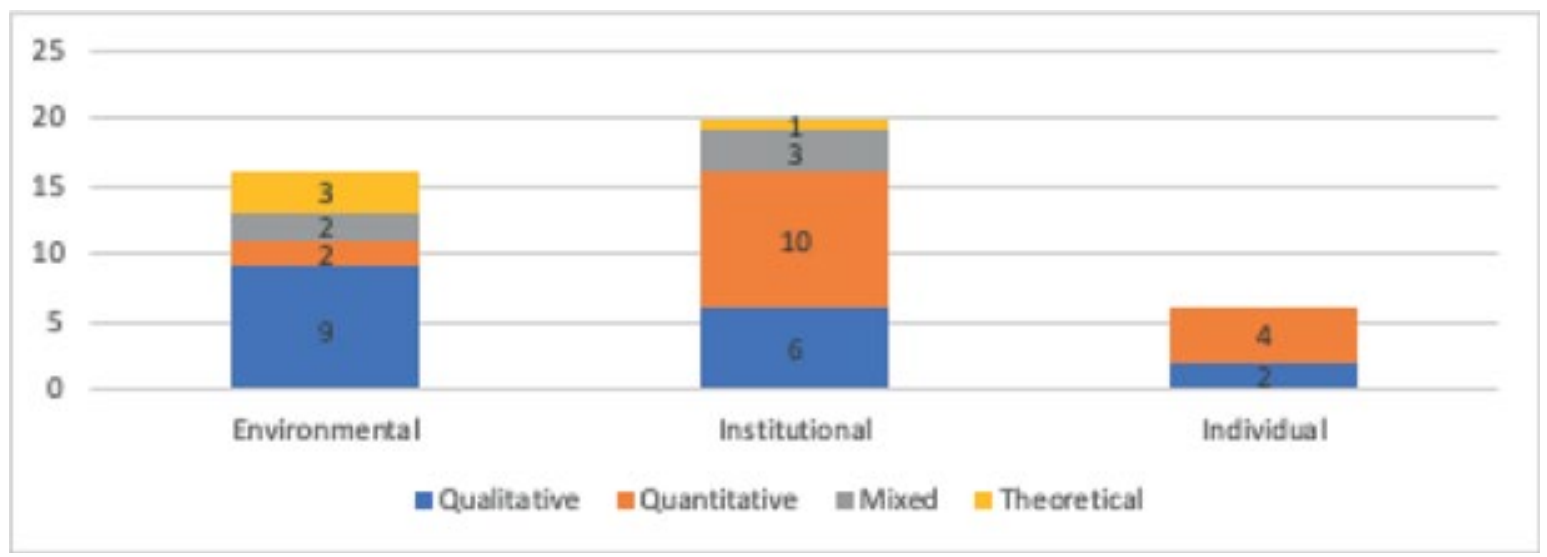

Figure 5. Investigations type in each cluster.

Notes. Elaborated by authors. 


\subsection{Research location}

Considering the sample, 21 countries and 1 continent were the geographical focus of researchers. Among the regions most studied, the United Kingdom (10) and the United States (9) stand out as the places that had the greatest attention. These two countries account for $41,3 \%$ of all research in the field. Denmark, China, Canada, Norway, Spain, Germany, as well as Europe as a set, received 2 papers each. Most investigations were performed in developed countries (82,6\%) in contrast with emerging $(17,4 \%)$. This tendency is observed in Environmental and Institutional clusters, while research in Individual cluster were slightly less concentrated. Figure 6 presents results by study location inside clusters.

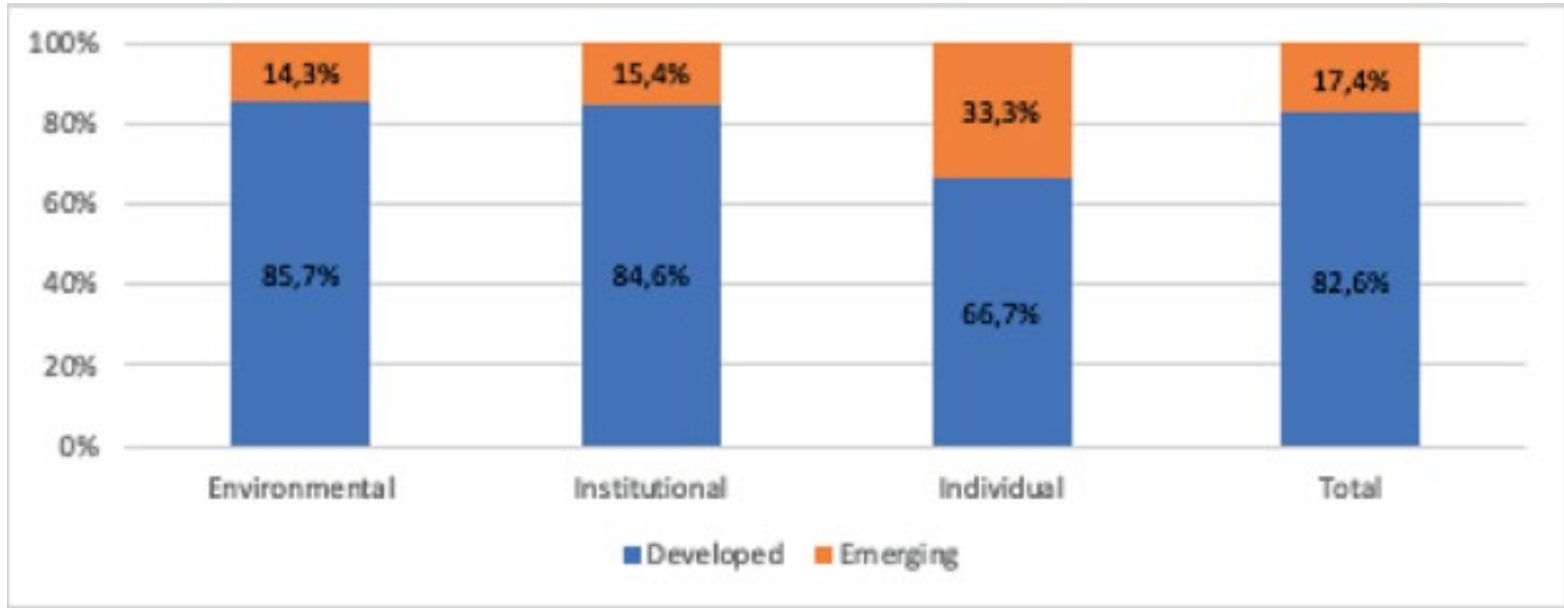

Figure 6. Research location by cluster. Notes. Elaborated by authors.

\section{CLUSTERS AND THEIR MAIN CONTRIBUTIONS}

Based on Deiaco et al. (2012) approach, a deep analysis of the papers allowed to divide the sample into three different clusters, according to the focus of the research: i) Environmental Impact; ii) Institutional Effectiveness, and iii) Individual Strategies. Tables number 4, number 5, and number 6 present, for each work, the number of citations, typology of the investigation, the place where the research was undertaken, core analysis, and key findings.

\subsection{Environmental Impact}

The first cluster contains 16 papers that focus on the analysis of the impacts of science institutions' KTT strategies on external stakeholders, whether firms, other universities, government agencies, or geographic regions, as shown in Table 4. There is a global pressure for universities to engage in collaborative relationships with external partners to disseminate basic knowledge, applied technology, and promote R\&D (Scott, 1998; Carayannis et al., 2000). Companies establish cooperative strategies with universities to strengthen innovation, internationalization, access to cutting-edge technologies, and an improvement of human resources (Paranhos et al., 2019; Santoro \& Chakrabarti, 2001; Paton et al., 2014). Nonprofit organizations and public administration can also benefit from alliances with research institutions through new initiatives, programs improvement, enhance competitive advantages, and fostering an innovative culture and ethics (Shaffer, 2012; Sharif \& Tang, 2014). 
Universities offer multiple engagement options that vary according to the institutional objectives of the partners (Frolund et al., 2018; Bergenholtz \& Bierregaard, 2014). The public agenda and the environment, however, might affect the behavior of academic institutions and their strategies for their financial outcomes. (Charles et al., 2014; McCarthy et al., 2018, Klofsten et al., 2019; Breznitz et al., 2008). Scientific institutions might contribute to the innovation efforts. Some universities mainly pursue a regional economic development agenda (Deiaco et al., 2012; Giuri et al., 2019). Literature, in turn, must expand the discussion of the impacts on university economics beyond science as a product to effectively assess the role of academic institutions in modern society (Hughes \& Kitson, 2012).

\subsection{Institutional Effectiveness}

The largest cluster reunites 20 studies investigating different scientific strategies of institutions to improve the performance for spreading knowledge and technology. Table 5 summarizes the key aspects of the papers. The support offered by specialized units, like incubators and Technology Transfer Offices (TTO), creates competitive advantages for academic institutions, as these structures have positive effects on licensing commercialization, spin-offs performance, and universities' equity participation in new ventures (Bengtsson, 2017; Soetanto \& Jack, 2016; Feldman et al., 2002). These units' success depends on human resources quality, administrative autonomy, and alignment with parent university strategic priorities and objectives (Somsuk \& Laosirihongthong, 2014; Mavi et al., 2019; Pitsakis \& Giachetti, 2020; Homer et al., 2019; Aragonés-Beltran et al., 2017).

The most successful universities on knowledge exchange have clear strategies toward the spinning-out of companies. They develop partnerships focused on R\&D contracts, form broad alliances with diverse corporate partners, synchronize resource accumulation with growth strategies, and concentrate KTT activities on consultancy and personal development (Lockett et al., 2003; Arvanitis \& Woerter, 2009; Lubik et al., 2013; Wright et al., 2012; Pickernell et al., 2019). It's paramount that this paper emphasizes that there is not only one formula that leads to KTT effective outcomes (Berbegal-Mirabent et al., 2020). The strategies must be tailored to the context (Özel \& Pénin, 2016; De Moortel \& Crispeels, 2018), as virtual teaming, exclusivity agreements, and proprietary forms of intellectual property (Hazlett \& Carayannis, 1998; Van der Berghe \& Guild, 2008; Andersen \& Rossi, 2011). For instance, it could leverage universities' results. By exploring contrasting scenarios on KTT strategies, a clear picture is provided regarding the competitive advantages the strategic knowledge transfer positioning offers. (Robertson et al., 2019).

\subsection{Individual Strategies}

The third cluster consists of 6 articles dedicated to investigating KTT strategies, as presented in Table 6. Universities, companies, and the public sector could lead the scientists to enhance the probability of technology commercialization success by providing incentive compensation, engaging inventors in products development, and creating policy programs that facilitate access to financing new ventures (Lee, 2017; Agrawal, 2006; Patzelt \& Shepherd, 2009). The influence of such stakeholders on individual behavior, however, has a limited capacity. The research groups are driven neither by policy rhetoric nor institutional statements. But by personal qualities and interests of group leaders (Kirs et al., 2017).

Relationships between academic faculty and private firms are complex. On the one hand, alliances established through consulting and applied research are critical for the new technologies' development (Chandran et al., 2015). On the other hand, apprehension of opportunistic behaviors creates obstacles to the knowledge dissemination process and increase cooperation management costs during the early stages (Guerrero et al., 2019). 

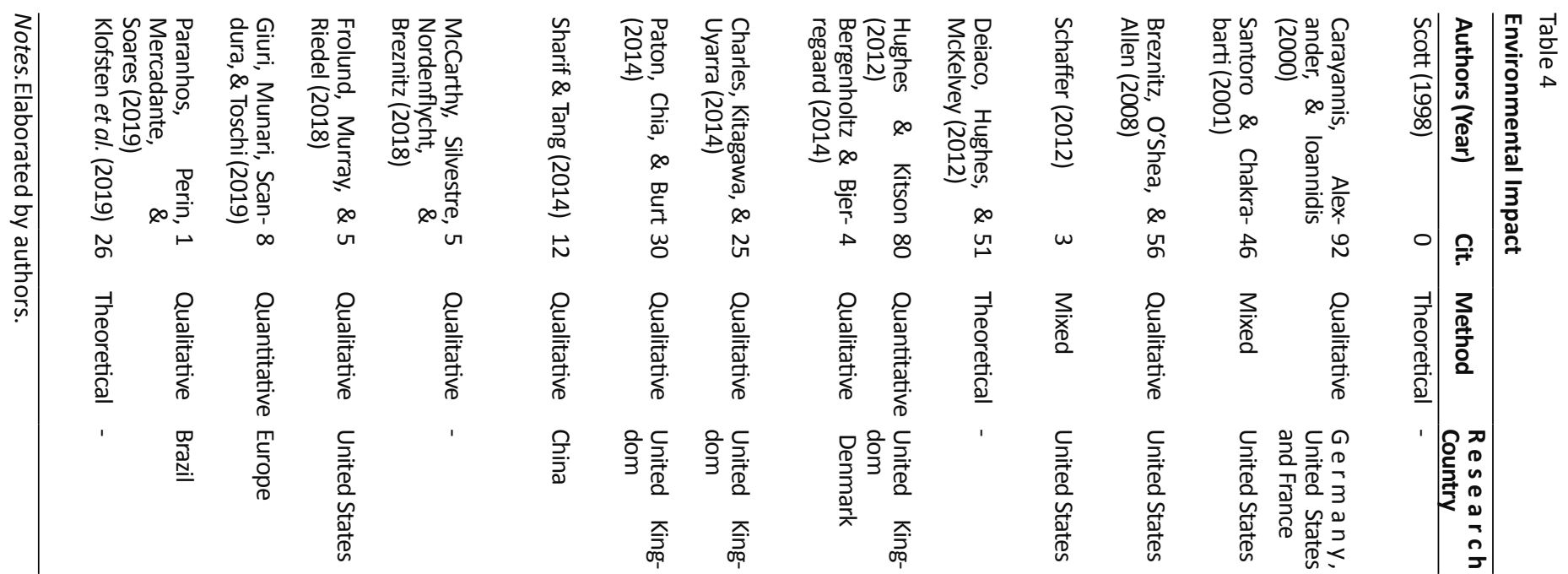

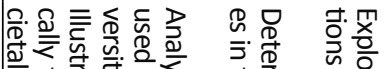

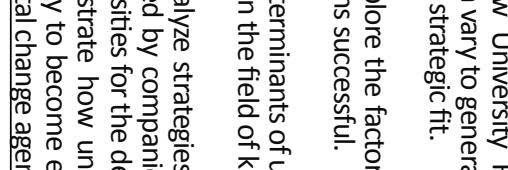

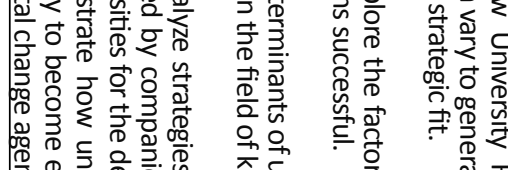

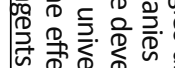

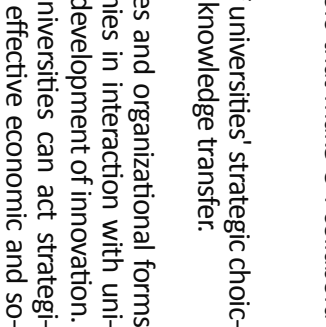

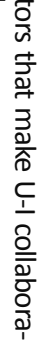

足

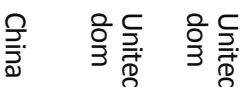

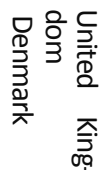

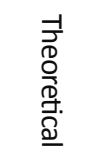

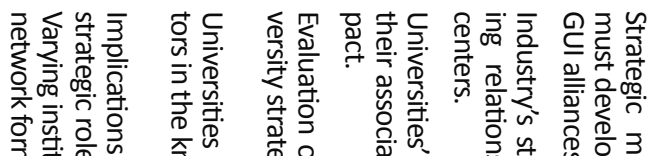

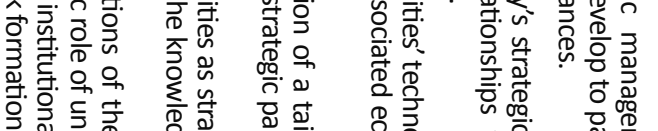

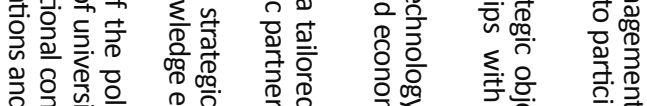

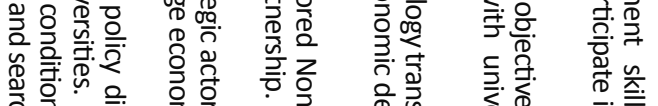

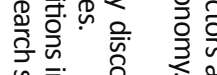

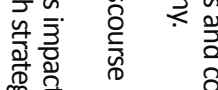

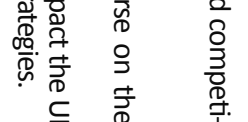

क्.

要离

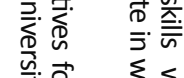

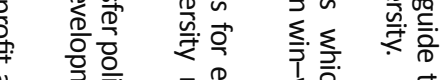

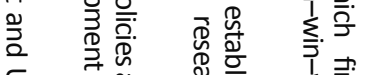

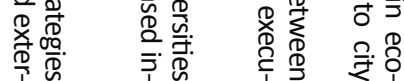

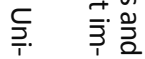

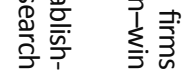

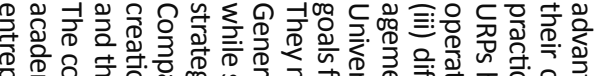

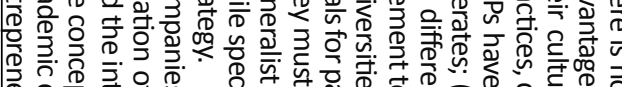

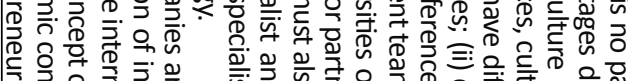

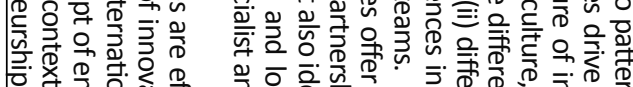

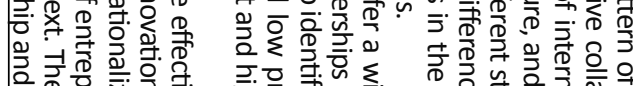

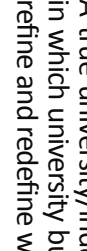

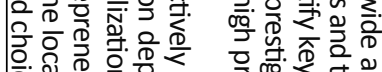

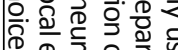

웅

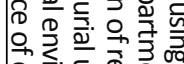

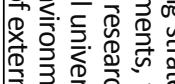

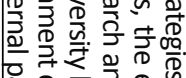

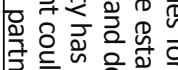

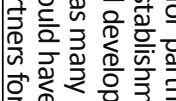

어에

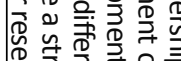

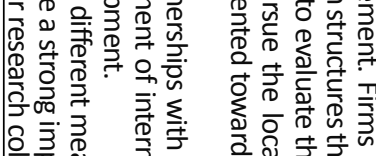
व.

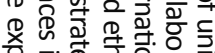

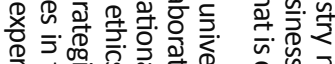

로동

5 중.

西.

尚

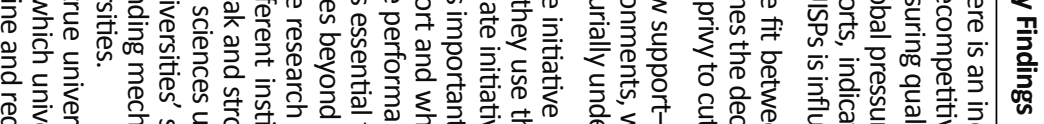

$\begin{array}{llll} & \\ 0 & \end{array}$

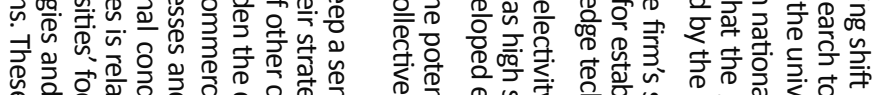

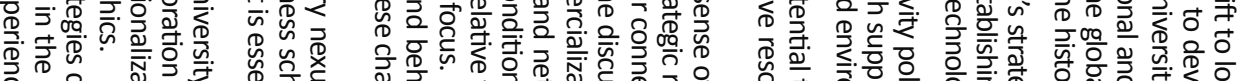

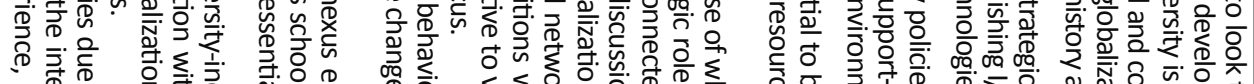

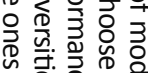

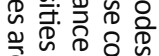

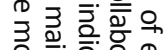

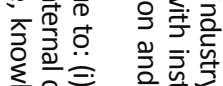

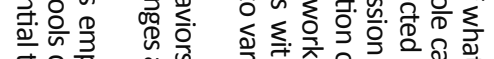

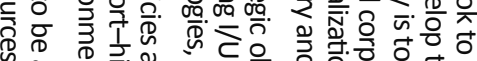

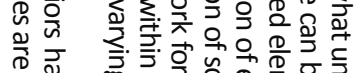

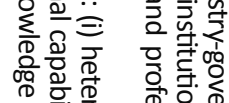

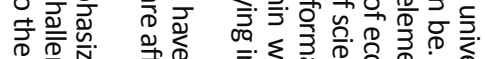

웅

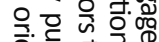

을ㅊ:웅

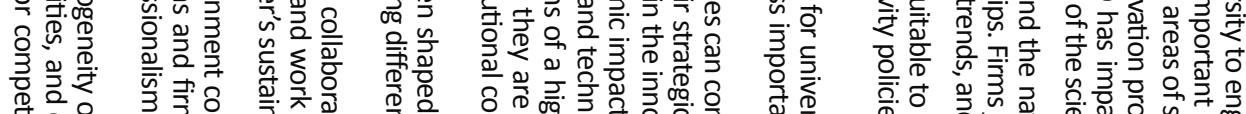

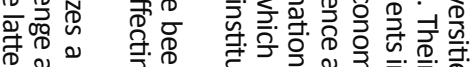

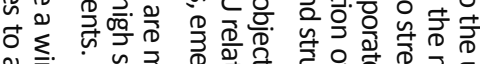

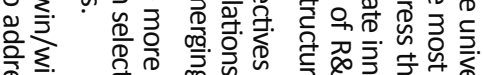

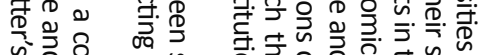

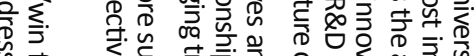

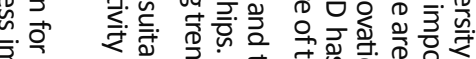

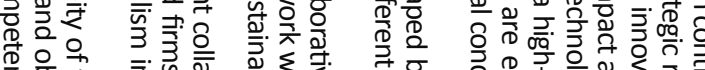

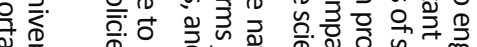

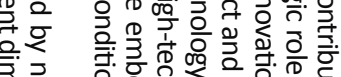

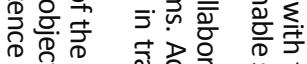

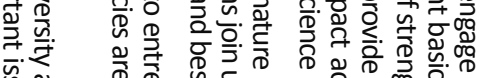

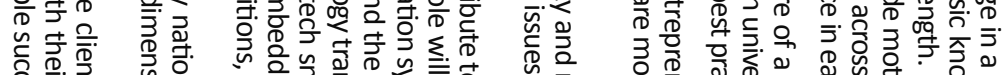

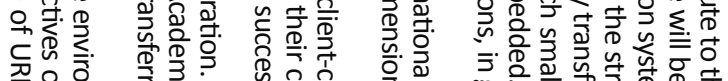

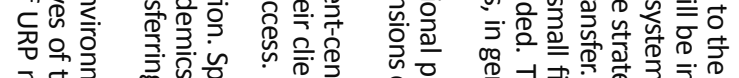

青家

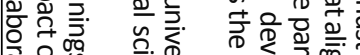

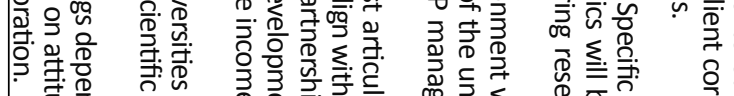

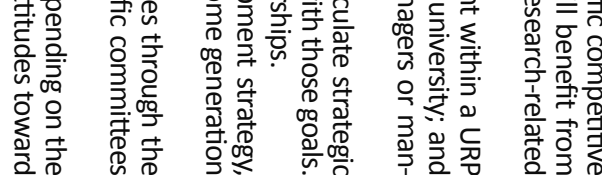

을

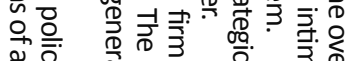

高

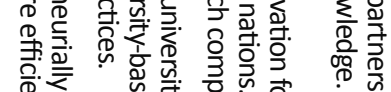

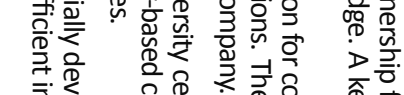

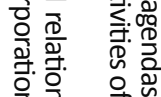

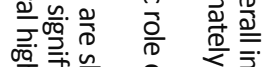

웅 亭

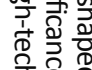

ज证

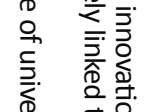

贾

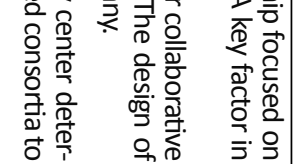




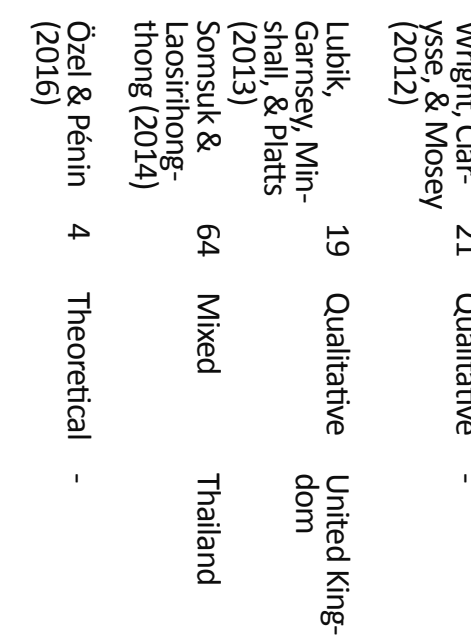

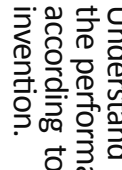

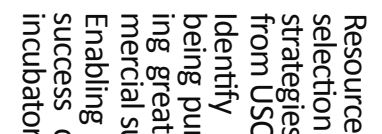

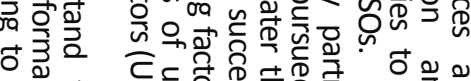

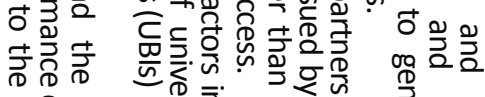

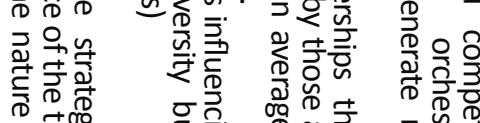

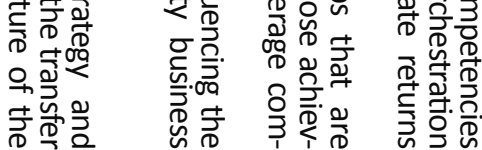

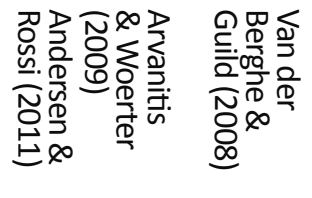

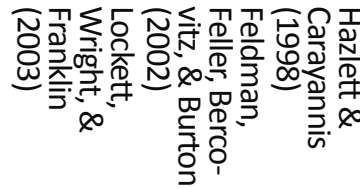

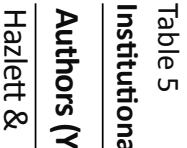

界虿

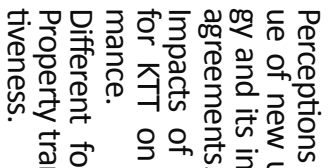

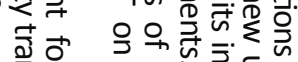

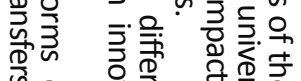

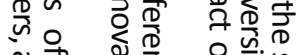

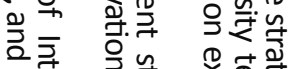

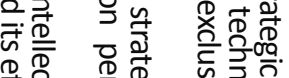

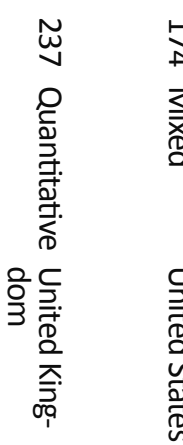

몸

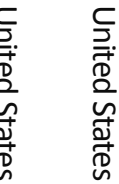

窝

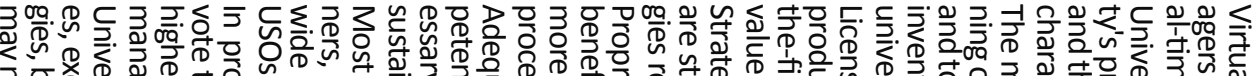

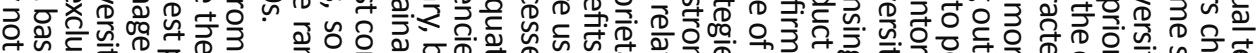

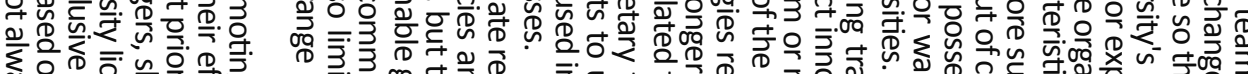

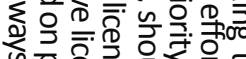

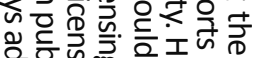

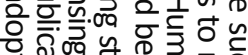

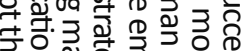

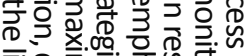

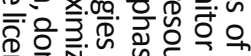
产.

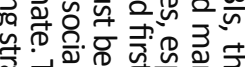

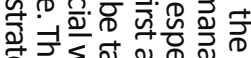

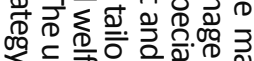

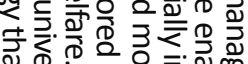

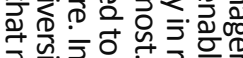

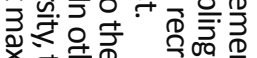
㲾.

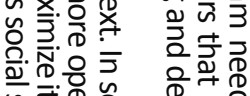

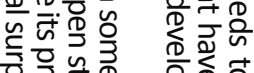

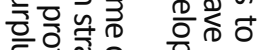

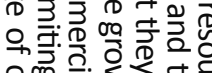

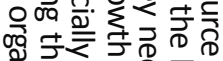

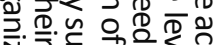

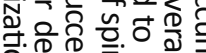
음율

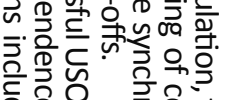

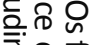

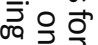
글 ำ

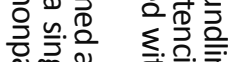

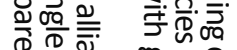
일

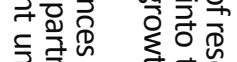
这点主

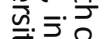

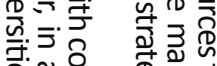

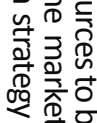

윽을

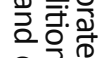

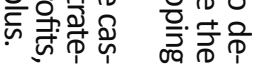

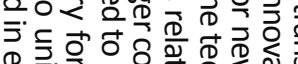

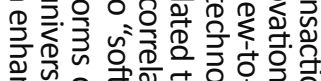

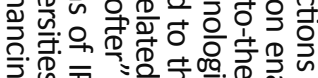

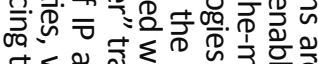

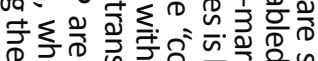

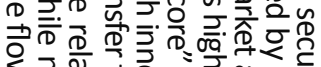

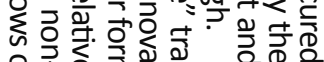

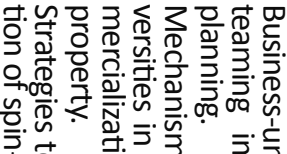

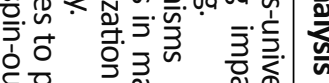

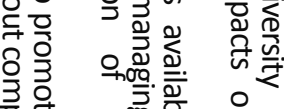

疍 움

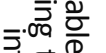

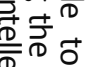

空 突

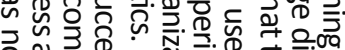

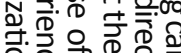

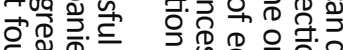

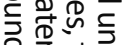

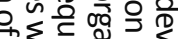

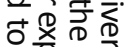

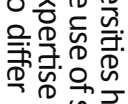
守守文

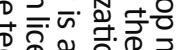

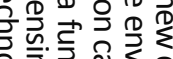

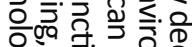

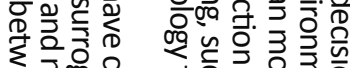

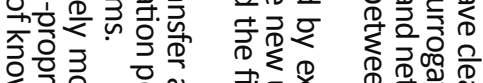

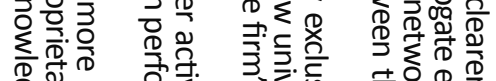

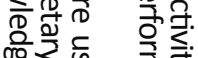
क्वर क

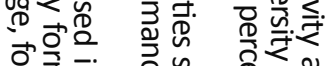

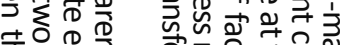

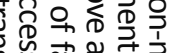

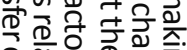

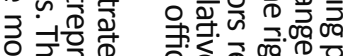

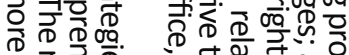

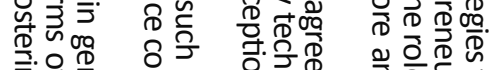

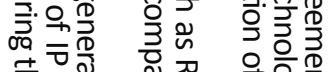

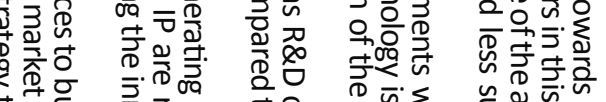

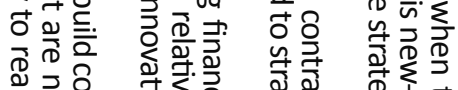

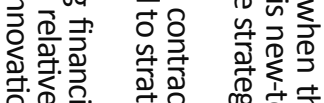

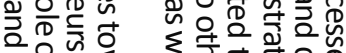

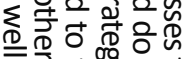

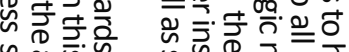

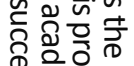

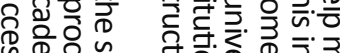

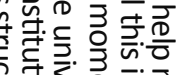

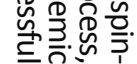




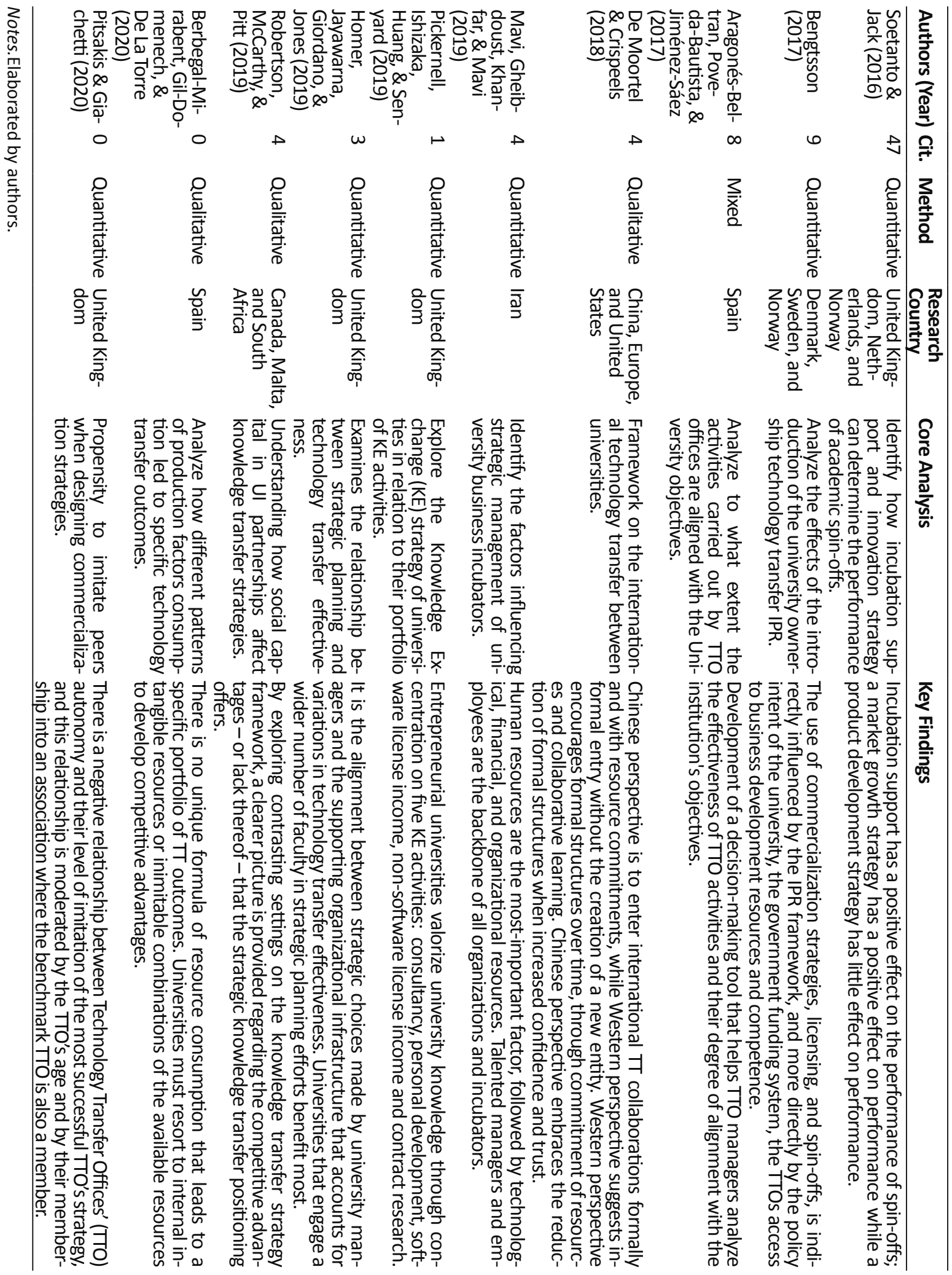




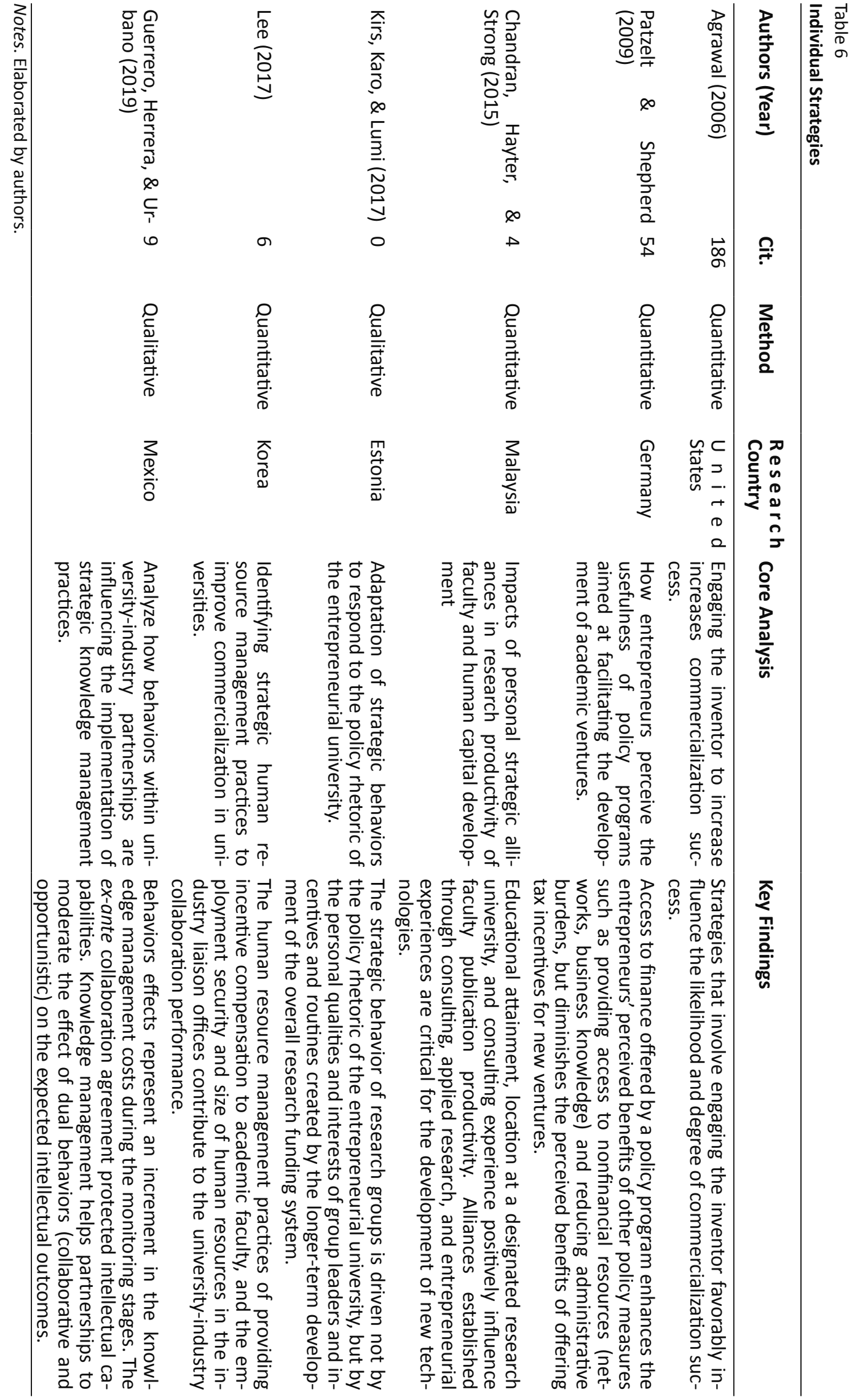

ReV. AdM. UfSM, SANTA MARIA, V. 14, Edição ESPECIAL ENGEMA, P. 1300-1324, 2021 


\section{DISCUSSION AND RESEARCH AGENDA}

The scientific reviews enable better identification of state of the art, which concerns the KTT strategies in scientific institutions. The researchers have a consensus that knowledge and technology dissemination strategies have a positive impact on society. It adds to the creation of new businesses, products, and services for the market. KTT strategies could expand the collective resources to address issues, improve programs, and create new brand initiatives. In addition to that, universities offer a wide array of engagement modes. The companies help to build new strategies for departments of innovations and the establishment of internal scientific committees. Successful KTT strategies favorably influence the spinning out of startups, the likelihood of technological commercialization, faculty publication productivity, and Intellectual Property registration. Such a strategy generates financial benefits to scientific institutions and fosters innovation processes and the development of new technologies. Some points, however, need further analysis yet, such as the role that the scientists play in developing products based on technology (Schaffer, 2012; Frolund et al., 2018; Paranhos et al., 2019; Lockett et al., 2003; Andersen \& Rossi, 2011; Agrawal, 2006; Chandran et al., 2015).

A good strategy for alignment is an essential factor to maximize the results of KTT activities between scientific institutions, private corporations, and governments. More important than the amount of physical and financial resources available to participants in technology transfer networks is knowing why to integrate this networking and which specific network an agent should connect. An option for being part of the tech transfer processes must be taken through a strategic analysis of the benefits and challenges that such collaborative activity will provide for the participants. There must be a clear KTT strategy along with predetermined objectives and goals to achieve optimal results (Santoro \& Chakrabarti, 2001; Lockett et al., 2003; Sharif \& Tang, 2014; Frolund et al., 2018, Paranhos et al., 2018).

In addition to that, the importance of human resources for effective KTT strategies must be considered. The human capital directly involved in KTT activities, going from knowledge creation to the management of support organisms, is a key resource for sound results. Institutions that seek to be at the frontier of innovation networks must improve and involve their best professionals throughout the process of strategic planning, management and control of knowledge and technology activities. There are solid indications that financial compensation, job stability, infrastructure of support and funding have direct impact on attracting qualified researchers (Hazlett \& Carayannis, 1998; Somsuk \& Laosirihongthong, 2014; Chandran et al., 2015; Soetanto \& Jack, 2016; Mavi et al., 2019).

Despite notable advances in literature, there is still a long way to go. First, it must be recognized that the geographical, social, institutional, political, and economic contexts have a profound impact on the effectiveness of KTT strategies in scientific institutions. In other words, one cannot expect a solution to emerge along a one size fits for all approach (De Moortel \& Crispeels, 2018; Klofsten et al., 2019; Berbegal-Mirabent et al., 2020).

Second, there are still doubts about the impact of the researchers' engagement in the entrepreneurial phase of the technologies they collaborated to develop. How can they contribute when the technology hits the market? Should scientists have a role in the management of the company, or should they act as technical consultants? These are questions where there are still no answers clarified by literature in the field (Lockett et al., 2003; Agrawal, 2006; Pickernell et al., 2019).

Finally, there are critical papers to a strictly commercial approach regarding KTT strategies. In view of the importance of the phenomenon for socioeconomic development and the complexity that involves the dissemination of knowledge, it is necessary to adopt other lenses to analyze in depth the different nuances of the problem, recognizing scientific institutions as a heritage of society (Deiaco et al., 2012; Hughes \& Kitson, 2012; Charles et al., 2014). 
Despite all this set of relevant conclusions reached by literature, there are yet some gaps that need further attention from the researchers in the field. Thus, the present study proposes a future research agenda to promote the advancement of understanding about KTT strategies. Table 7 contains twelve research questions, divided among the three clusters, which can serve as a guide for further investigations in the theme. The proposals were based on issues where there is still no consensus in the scientific community; in the context of declaration of emergency in public health of international importance by the World Health Organization, because of the COVID-19 pandemic; and, finally, on topics that demand current attention from researchers, such as climate change and immigration crises.

Table 7

Proposed future research agenda

\begin{tabular}{ll}
\hline Cluster & Research Question \\
\hline & What are the non-economic impacts, such as maintenance of immaterial and \\
historical-cultural heritage, of KTT activities in society? & What KTT strategies are being implemented by emerging countries to reduce \\
the development gap in relation to wealthy countries? & What are the impacts of KTT strategies in worldwide problems, such as global \\
Wnvironmental Impact & How can different KTT strategies contribute to the improvement and effective- \\
& ness of public policies? \\
\hline & How can scientific institutions improve KTT performance metrics to include \\
& non-economic goals? \\
& Which KTT strategies adopted by scientific institutions located in developing \\
countries can overcome barriers and restrictions imposed by a challenging ex- \\
ternal environment? \\
Which KTT strategies are effective in remote work and social distancing con- \\
texts? \\
What are the impacts of different KTT strategies in increasing scientific institu- \\
tions credibility and consequent reduction in the spread of fake news? \\
How to engage researchers from different areas of scientific knowledge, such \\
as social, natural, philosophical, and artistic sciences, in KTT activities? \\
How do professors feel about superior pressure to reconcile their teaching \\
mainstream activities with KTT activities? \\
What role should researchers play in the businesses that emerge after the \\
development of new technologies? \\
Do students feel pressured to integrate projects or develop KTT activities de- \\
fined by professors, even if they are not in an area of interest?
\end{tabular}

Notes. Elaborated by authors.

\section{CONCLUSION}

The objective of the present study is to understand the current state of the academic debate regarding knowledge and technology transfer strategies in scientific institutions. Through a Systematic Literature Review it was possible to identify the advances and consensus reached by most prominent research in the field, undertake a descriptive quantitative analysis of relevant publications, and recognize avenues that have not been explored or that lack more empirical evidence to pacify controversies on certain issues.

Literature might be segmented according to the macro, meso or micro level approach of authors, enabling the emergence of three main research clusters. They regard the focus on each study: environmental impact, institutional effectiveness, and individual strategies. The quantitative 
analysis of the sample allows to infer that this is a recent topic in which the current decade brings together approximately $74 \%$ of all publications. In addition, there is a trend of reversal in the focus of investigations, with the research in the last five years focusing on institutional analysis to the detriment of the environmental one. Regarding the typology of studies, qualitative and quantitative works have practically the same importance among the authors in this field. It is also worth noting the need for decreasing the geographic concentration of research in KTT strategies, given that almost $85 \%$ of the studies focused on develop countries.

From the literature review it was possible to highlight relevant results of KTT strategies in scientific institutions. Successful strategies can leverage innovation processes, generating greater financial benefits for scientific institutions through Intellectual Property contracts. In addition, they increase the likelihood of product's commercialization, the productivity of faculty engaged in technological development and the performance of startups that have gone through the incubation process and resulted in spin offs.

An effective knowledge and technology transfer policy is only possible, however, from the alignment of these activities with the strategic objectives of the institutions involved in innovation networks. Besides, the most important resource in the development and application of efficient KTT strategies is human capital, which must be properly selected, trained, and engaged in the entire process of knowledge dissemination to society. Finally, the different existing technology commercialization strategies must be adapted to socioeconomic contexts of the actors involved in the process, with no single or winning recipe for the transmission of knowledge.

Admitting the need to further the knowledge to deepen the process of the consolidation of the literature on KTT strategies in scientific institutions, a research agenda was proposed based on identified gaps. Such topics in previous studies did not reach a consensus on emerging themes in an increasingly digital, globalized, and dynamic world.

The results presented must be interpreted cautiously due to the limitations of the study. First, only one database was used. Although Web of Science is the platform that works with the most scientific publications, other relevant databases like Scopus were not consulted, limiting the study's range. The choice for only one database is because Vieira and Gomes (2009) found evidence that the most relevant studies are indexed in both platforms. Another limitation is due to the option to compose the sample only with papers written in English. Despite being the most used language in scientific publications (Sandelin \& Sarafoglu, 2004), untranslated papers that were developed in Latin America, Continental Europe, Africa, and Asia were excluded from this analysis.

As the main contributions of the paper, they can be listed on three different fronts. In the methodological aspect, the implemented technique allows the replicability of the study by third parties to validate the results or the use of the research protocol in other databases to expand the knowledge in the field. By proposing a future research agenda, the work seeks to advance the development and consolidation of a theoretical framework on KTT strategies, illustrating research gaps that need a greater scrutiny by specialized literature. Finally, from a managerial point of view, this investigation contributes by systematically discussing the main results and impacts of different scientific institutions' KTT strategies, supporting the decision-making by leaders of these organizations in the search for efficient strategies for themselves. 


\section{REREFENCE}

Agrawal, A. (2006). Engaging the inventor: Exploring licensing strategies for university inventions and the role of latent knowledge. Strategic Management Journal, 27(1), 63-79.

Andersen, B., \& Rossi, F. (2011). UK universities look beyond the patent policy discourse in their intellectual property strategies. Science and Public Policy, 38(4), 254-268.

Aragonés-Beltrán, P., Poveda-Bautista, R., \& Jiménez-Sáez, F. (2017). An in-depth analysis of a TTO’s objectives alignment within the university strategy: An ANP-based approach. Journal of Engineering and Technology Management, 44, 19-43.

Arvanitis, S., Kubli, U., \& Woerter, M. (2008). University-industry knowledge and technology transfer in Switzerland: What university scientists think about co-operation with private enterprises. Research Policy, 37(10), 1865-1883.

Arvanitis, S., \& Woerter, M. (2009). Firms' transfer strategies with universities and the relationship with firms' innovation performance. Industrial and Corporate Change, 18(6), 1067-1106.

Audretsch, D. B., Lehmann, E. E., \& Wright, M. (2014). Technology transfer in a global economy. The Journal of Technology Transfer, 39(3), 301-312.

Autant-Bernard, C. (2001). Science and knowledge flows: evidence from the French case. Research Policy, 30(7), 1069-1078. doi: https://doi.org/10.1016/S0048-7333(00)00131-1.

Battistella, C., De Toni, A. F., \& Pillon, R. (2016). Inter-organisational technology/knowledge transfer: a framework from critical literature review. The Journal of Technology Transfer, 41(5), 11951234.

Bengtsson, L. (2017). A comparison of university technology transfer offices' commercialization strategies in the Scandinavian countries. Science and Public Policy, 44(4), 565-577.

Berbegal-Mirabent, J., Gil-Doménech, D., \& Eva, M. (2020). Examining strategies behind universities' technology transfer portfolio: how different patterns of resource consumption can lead to similar technology transfer profiles. Competitiveness Review: An International Business Journal.

Bercovitz, J., \& Feldman, M. (2006). Entpreprenerial universities and technology transfer: A conceptual framework for understanding knowledge-based economic development. The Journal of Technology Transfer, 31(1), 175-188.

Bergenholtz, C., \& Bjerregaard, T. (2014). How institutional conditions impact university-industry search strategies and networks. Technology Analysis \& Strategic Management, 26(3), 253266.

Bou-Llusar, J. C., \& Segarra-Ciprés, M. (2006). Strategic knowledge transfer and its implications for competitive advantage: an integrative conceptual framework. Journal of knowledge management.

Breznitz, S. M., O'Shea, R. P., \& Allen, T. J. (2008). University commercialization strategies in the development of regional bioclusters. Journal of Product Innovation Management, 25(2), 129142. 
Carayannis, E. G., Alexander, J., \& loannidis, A. (2000). Leveraging knowledge, learning, and innovation in forming strategic government-university-industry (GUI) R\&D partnerships in the US, Germany, and France. Technovation, 20(9), 477-488.

Chandran, V. G. R., Hayter, C. S., \& Strong, D. R. (2015). Personal strategic alliances: enhancing the scientific and technological contributions of university faculty in Malaysia. Economics of Innovation and New Technology, 24(5), 421-435.

Charles, D., Kitagawa, F., \& Uyarra, E. (2014). Universities in crisis? - new challenges and strategies in two English city-regions. Cambridge journal of regions, economy and society, 7(2), 327-348.

Cottrill, C. A., Rogers, E. M., \& Mills, T. (1989). Co-citation analysis of the scientific literature of innovation research traditions: Diffusion of innovations and technology transfer. Knowledge, 11(2), 181208.

Curi, C., Daraio, C., \& Llerena, P. (2012). University technology transfer: how (in) efficient are French universities?. Cambridge journal of economics, 36(3), 629-654.

De Moortel, K., \& Crispeels, T. (2018). International university-university technology transfer: Strategic management framework. Technological Forecasting and Social Change, 135, 145155.

Deiaco, E., Hughes, A., \& McKelvey, M. (2012). Universities as strategic actors in the knowledge economy. Cambridge Journal of Economics, 36(3), 525-541.

Diniz, D. M., \& de Castro, J. M. (2010). Processo de gestão estratégica em universidades privadas: Um estudo de casos. Revista de Administração da Universidade Federal de Santa Maria, 3(3), 311-325.

Eloranta, V., \& Turunen, T. (2015). Seeking competitive advantage with service infusion: a systematic literature review. Journal of Service Management.

Etzkowitz, H. (2013). Anatomy of the entrepreneurial university. Social Science Information, 52(3), 486-511.

Feldman, M., Feller, I., Bercovitz, J., \& Burton, R. (2002). Equity and the technology transfer strategies of American research universities. Management Science, 48(1), 105-121.

Friedman, J., \& Silberman, J. (2003). University technology transfer: do incentives, management, and location matter?. The Journal of technology transfer, 28(1), 17-30.

Frølund, L., Murray, F., \& Riedel, M. (2018). Developing successful strategic partnerships with universities. MIT Sloan management review, 59(2), 71-79.

Giuri, P., Munari, F., Scandura, A., \& Toschi, L. (2019). The strategic orientation of universities in knowledge transfer activities. Technological Forecasting and Social Change, 138, 261-278.

Giusepponi, K., \& Tavoletti, E. (2018). Vision and Mission Statments in Italian Universities: Results of Empirical Investigation on Strategic Orientation. Journal of the Knowledge Economy, 9(1), 301328. doi: 10.1007/s13132-015-0343-7. 
Govind, M., \& Küttim, M. (2017). International knowledge transfer from university to industry: A systematic literature review. Research in economics and business: central and eastern europe, 8(2).

Guerrero, M., Herrera, F., \& Urbano, D. (2019). Strategic knowledge management within subsidised entrepreneurial university-industry partnerships. Management Decision.

Hadengue, M., de Marcellis-Warin, N., \& Warin, T. (2017). Reverse innovation: a systematic literature review. International Journal of Emerging Markets.

Hall, J. C. (2006). Positive Externalities and Government Involvement in Education. Journal of Private Enterprise, 21(2), 165-175.

Hausberg, J. P., \& Korreck, S. (2020). Business incubators and accelerators: a co-citation analysisbased, systematic literature review. The Journal of Technology Transfer, 45(1), 151-176.

Hazlett, J. A., \& Carayannis, E. G. (1998). Business-university virtual teaming for strategic planning. Technological Forecasting and Social Change, 57(3), 261-265.

Helfat, C.E. \& Peteraf, M.A. (2003). The dynamic resource-based view: capability lifecycles, Strategic Management Journal, 24(10), 997-1010.

Horner, S., Jayawarna, D., Giordano, B., \& Jones, O. (2019). Strategic choice in universities: Managerial agency and effective technology transfer. Research Policy, 48(5), 1297-1309.

Hughes, A., \& Kitson, M. (2012). Pathways to impact and the strategic role of universities: new evidence on the breadth and depth of university knowledge exchange in the UK and the factors constraining its development. Cambridge journal of economics, 36(3), 723-750.

Keupp, M. M., Palmié, M., \& Gassmann, O. (2012). The strategic management of innovation: A systematic review and paths for future research. International journal of management reviews, 14(4), 367-390.

Kirs, M., Karo, E., \& Lumi, P. (2017). Strategic behaviour of research groups within the entrepreneurial university policy rhetoric: the Estonian biotechnology sector. Science and Public Policy, 44(6), 802-820.

Klofsten, M., Fayolle, A., Guerrero, M., Mian, S., Urbano, D., \& Wright, M. The entrepreneurial university as driver for economic growth and social change - Key strategic challenges. Technological Forecasting \& Social Change, 141, 149-158. doi: 10.1016/j.techfore.2018.12.004.

Kraus, S., Breier, M., \& Dasí-Rodríguez, S. (2020). The art of crafting a systematic literature review in entrepreneurship research. International Entrepreneurship and Management Journal, 16(3), 1023-1042.

Kraus, S., Mahto, R. V., \& Walsh, S. T. (2021). The importance of literature reviews in small business and entrepreneurship research.

Laredo, P. (2007). Revisiting the Third Mission of Universities: Toward a Renewed Categorization of University Activities? Higher Education Policy, 20, 441-456. doi: https://doi.org/10.1057/ palgrave.hep.8300169. 
Lavie, D. (2006). The competitive advantage of interconnected firms: an extension of theresourcebased view, Academy of Management Review, 31(3), 638-658.

Lee, K. J. (2018). Strategic human resource management for university-industry collaborations in Korea: financial incentives for academic faculty and employment security of industry liaison offices. Technology Analysis \& Strategic Management, 30(4), 461-472.

Lockett, A., Wright, M., \& Franklin, S. (2003). Technology transfer and universities' spin-out strategies. Small business economics, 20(2), 185-200.

Lubik, S., Garnsey, E., Minshall, T., \& Platts, K. (2013). Value creation from the innovation environment: partnership strategies in university spin-outs. R\&D Management, 43(2), 136-150.

Major, E. (2003). Technology transfer and innovation initiatives in strategic management: generating an alternative perspective. Industry and Higher Education, 17(1), 21-27.

Malerba, R. C., \& Ferreira, J. J. (2020). Immigrant entrepreneurship and strategy: a systematic literature review. Journal of Small Business \& Entrepreneurship, 1-35.

Mascarenhas, C., Ferreira, J. J., \& Marques, C. (2018). University-industry cooperation: A systematic literature review and research agenda. Science and Public Policy, 45(5), 708-718.

Mavi, R. K., Gheibdoust, H., Khanfar, A. A., \& Mavi, N. K. (2019). Ranking factors influencing strategic management of university business incubators with ANP. Management Decision.

McCarthy, I. P., Silvestre, B. S., von Nordenflycht, A., \& Breznitz, S. M. (2018). A typology of university research park strategies: What parks do and why it matters. Journal of Engineering and Technology Management, 47, 110-122.

Nag, R., Hambrick, D. C., \& Chen, M. -J. (2007). What is strategic management, really? Inductive derivation of a consensus definition of the field. Strategic Management Journal, 28(9), 935955. doi: 10.1002/smj.615.

Özel, S. Ö., \& Pénin, J. (2016). Exclusive or open? An economic analysis of university intellectual property patenting and licensing strategies. Journal of Innovation Economics Management, (3), 133-153.

Paranhos, J., Perin, F. S., Mercadante, E., \& Soares, C. (2019). Industry-university interaction strategies of large Brazilian pharmaceutical companies. Management Research: Journal of the Iberoamerican Academy of Management.

Paton, S., Chia, R., \& Burt, G. (2014). Relevance or 'relevate'? How university business schools can add value through reflexively learning from strategic partnerships with business. Management Learning, 45(3), 267-288.

Patzelt, H., \& Shepherd, D. A. (2009). Strategic entrepreneurship at universities: Academic entrepreneurs' assessment of policy programs. Entrepreneurship Theory and practice, 33(1), 319-340.

Perkmann, M., Tartari, V., McKelvey M., Autio, E., Broström, A., D’Este, P., Fini, R., Geuna, A., Grimaldi, R., Hughes, A., Krabel, S., Kitson, M., Llerena, P., Lissoni, F., Salter, A., \& Sobrero, M. (2013). Academic engagement and commercialisation: A review of literature on university-industry relations. Research Policy, 42(2), 423-442. doi: 10.1016/j.respol.2012.09.007. 
Pickernell, D., Ishizaka, A., Huang, S., \& Senyard, J. (2019). Entrepreneurial university strategies in the UK context: towards a research agenda. Management Decision.

Pitsakis, K., \& Giachetti, C. (2020). Information-based imitation of university commercialization strategies: The role of technology transfer office autonomy, age, and membership into an association. Strategic Organization, 18(4), 573-616.

Robertson, J., McCarthy, I. P., \& Pitt, L. (2019). Leveraging social capital in university-industry knowledge transfer strategies: A comparative positioning framework. Knowledge Management Research \& Practice, 17(4), 461-472.

Sandelin, B., \& Sarafoglou, N. (2004). Language and scientific publication statistics. Language Problems and Language Planning, 28(1), 1-10.

Santoro, M. D., \& Chakrabarti, A. K. (2001). Corporate strategic objectives for establishing relationships with university research centers. IEEE Transactions on Engineering Management, 48(2), 157163.

Schaffer, R. H. (2012). Nonprofit and university strategic partnerships to strengthen the sector. Nonprofit Management and Leadership, 23(1), 105-119.

Scott, N. R. (1998). Strategy for activating university research. Technological forecasting and social change, 57(3), 217-219.

Sharif, N., \& Tang, H. H. H. (2014). New trends in innovation strategy at Chinese universities in Hong Kong and Shenzhen. International Journal of Technology Management, 65(1-4), 300-318.

Siegel, D. S., Veugelers, R., \& Wright, M. (2007). Technology transfer offices and commercialization of university intellectual property: performance and policy implications. Oxford review of economic policy, 23(4), 640-660.

Soetanto, D., \& Jack, S. (2016). The impact of university-based incubation support on the innovation strategy of academic spin-offs. Technovation, 50, 25-40.

Somsuk, N., \& Laosirihongthong, T. (2014). A fuzzy AHP to prioritize enabling factors for strategic management of university business incubators: Resource-based view. Technological forecasting and social change, 85, 198-210.

Sousa, D., de Brito, M. J., \& Zambalde, A. L. (2019). Marketing roles of university technology transfer offices: a systematic review. Revista de Administração da Universidade Federal de Santa Maria, 12(1), 26-40.

Szopa, A. (Ed.). (2015). Competitive Strategies for Academic Entrepreneurship: Commercialization of Research-Based Products: Commercialization of Research-Based Products. IGI Global.

Tatikonda, M. V., \& Stock, G. N. (2003). Product technology transfer in the upstream supply chain. Journal of product innovation management, 20(6), 444-467.

Teece, D.J. (2007). Explicating dynamic capabilities: the nature and microfoundations of (sustainable) enterprise performance, Strategic Management Journal, Vol. 28 No. 13, 1319-1350. 
Van den Berghe, L., \& Guild, P. D. (2008). The strategic value of new university technology and its impact on exclusivity of licensing transactions: An empirical study. The Journal of Technology Transfer, 33(1), 91-103.

Vieira, E., \& Gomes, J. (2009). A comparison of Scopus and Web of Science for a typical university. Scientometrics, 81(2), 587-600.

Weber, J., \& Watson, R. T. (2002). Analyzing the past to prepare for the future: writing a literature review. MIS Quartely, 26(2), 13-23.

Wright, M., Clarysse, B., \& Mosey, S. (2012). Strategic entrepreneurship, resource orchestration and growing spin-offs from universities. Technology analysis \& strategic management, 24(9), 911927.

Wu, W., \& Zhou, Y. (2012). The third mission stalled? Universities in China's technological progress. Journal of Technology Transfer, 37, 812-827. doi: 10.1007/s10961-011-9233-8. 


\section{AUTHORS}

\section{Matheus Dantas Madeira Pontes}

Institution: University of International Integration of Afro-Brazilian Lusophony (PROPLAN/UNILAB). Redenção, Ceará, Brazil.

Ph.D. candidate in Management at the University of Beira Interior. Master in Administration from the State University of Ceará (UECE). Economist at the University of International Integration of Afro-Brazilian Lusophony (UNILAB).

E-mail: matheus.pontes@unilab.edu.br

ORCID: https://orcid.org/0000-0002-0056-2826

\section{Thayanne Lima Duarte Pontes}

Institution: University of Beira Interior (NECE/UBI). Covilhã, Portugal.

Ph.D. candidate in Management at the University of Beira Interior, Covilhã, Portugal. Master in Administration from University Potiguar, Natal, Brazil.

E-mail: thayanne.pontes@ubi.pt

ORCID: https://orcid.org/0000-0002-8438-9660

\section{Contribution of authors}

Every author should account for at least one component of the work. Paper approved for publication need to specify the contribution of every single author.

\begin{tabular}{|c|c|c|}
\hline Contribution & [Author 1] & [Author 2] \\
\hline 1. Definition of research problem & $\mathrm{V}$ & \\
\hline $\begin{array}{l}\text { 2. Development of hypotheses or research questions (empirical stud- } \\
\text { ies) }\end{array}$ & $\sqrt{ }$ & $\sqrt{ }$ \\
\hline \multicolumn{3}{|l|}{$\begin{array}{l}\text { 3. Development of theoretical propositions } \\
\text { (theoretical work) }\end{array}$} \\
\hline 4. Theoretical foundation / Literature review & $\sqrt{ }$ & $\sqrt{ }$ \\
\hline 5. Definition of methodological procedures & & $\sqrt{ }$ \\
\hline 6. Data collection & $\mathrm{V}$ & \\
\hline 7. Statistical analysis & $\mathrm{V}$ & $\sqrt{ }$ \\
\hline 8. Analysis and interpretation of data & $\sqrt{ }$ & \\
\hline 9. Critical revision of the manuscript & $\sqrt{V}$ & $\sqrt{ }$ \\
\hline 10. Manuscript writing & $\bar{V}$ & $\sqrt{\mathrm{V}}$ \\
\hline 11. Other (please specify) & & \\
\hline
\end{tabular}

\section{Conflict of Interest}

The authors have stated that there is no conflict of interest.

Copyrights

ReA/UFSM owns the copyright to this content.

Plagiarism Check

The ReA/UFSM maintains the practice of submitting all documents approved for publication to the plagiarism check, using specific tools, e.g.: CopySpider. 